\title{
Development of an Efficient Particle Bombardment Transformation System for the Endemic Orchid, Phalaenopsis bellina
}

(Pembentukan Sistem Transformasi Pembedilan Zarah yang Cekap bagi Orkid Endemik, Phalaenopsis bellina)

\author{
YeE-Chern Chew, Wan Muhamad Asrul Nizam Wan AbDullah, De-Xian ANDREW KoK, \\ JANNA ONG-ABDULLAH, MAZIAH MAHMOOD \& KOK-SONG LAI*
}

\begin{abstract}
Phalaenopsis bellina is an important indigenous orchid with high commercial value. In this study, we established an efficient particle bombardment transformation system for P. bellina using the protocorm-like-bodies (PLBS) as target tissues. Leaf derived PLBS were proliferated on $1 / 2$ strength Murashige and Skoog (MS) medium supplemented with 0.8 $\mu M$ 2,4 dichlorophenoxyacetic acid $(2,4-D)$. Both physical and biological parameters affecting the transformation system were optimised using the green-fluorescent protein (GFP) and $\beta$-glucuronidase (GUS) as reporter systems. Optimal bombardment conditions with $6 \mathrm{~cm}$ target tissues distance, 1100 psi acceleration pressure, 1.0 um gold particle size, 27 mmHg chamber vacuum pressure, single bombardment time, spermidine as DNA precipitation agent, 72 h post bombardment incubation time, $2 \mu \mathrm{g}$ plasmid DNA in 0.15:0.12 pmol ratio (pSMCHS:p35SGFP) were successfully determined. Surviving PLBs transformants were successfully recovered from the hygromycin selection medium and verified using genomic PCR analysis. The established system is not only useful for a simple and reliable transient gene analysis but as well as generating stable transformants for selective traits improvement in orchids.
\end{abstract}

Keywords: $\beta$-glucuronidase (GUS); green fluorescent protein (GFP); particle bombardment; Phalaenopsis bellina; protocorm-like-bodies (PLBS)

\section{ABSTRAK}

Phalaenopsis bellina ialah salah suatu orkid yang mempunyai nilai komersial yang tinggi. Dalam kajian ini, kami telah membentuk sistem transformasi pembedilan zarah yang berkesan untuk P. bellina menggunakan jasad seperti protokorm (PLB) sebagai tisu sasaran. Daun daripada PLBs bercambah pada 1/2 kekuatan medium Murashige dan Skoog (MS) yang mengandungi $0.8 \mu M$ 2,4 asid d diklorofenok siasetik (2, 4-D). Parameter biologi dan fizikal yang mempengaruhi sistem transformasi telah dioptimumkan dengan menggunakan protein fluoresen hijau (GFP) dan $\beta$ - glukuronidase (GUS) sebagai sistem pelapor. Keadaan pembedilan optimum dengan jarak tisu $6 \mathrm{~cm}$, tekanan pecutan 1100 psi, saiz zarah $1.0 \mu$ m, tekanan vakum $27 \mathrm{mmHg}$, pembedilan tunggal, spermidine sebagai agen pemendapan DNA, 72 jam tempoh inkubasi selepas pembedilan, $2 \mu \mathrm{g}$ DNA plasmid dalam 0.15:0.12 pmol nisbah (pSMCHS:p35SGFP) telah ditentukan. Transforman PLB telah berjaya dipulihkan selepas inkubasi di dalam medium pemilihan higromisin dan disahkan menggunakan analisis PCR genom. Sistem yang ditubuhkan ini tidak hanya berguna untuk analisis gen sementara yang boleh dipercayai dan mudah tetapi juga mampu menjana transformasi stabil bagi peningkatan ciri-ciri terpilih dalam orkid.

Kata kunci: $\beta$ - glukuronidase (GUS); jasad seperti protokorm (PLB); Phalaenopsis bellina; pembedilan zarah; protein fluoresen hijau (GFP)

\section{INTRODUCTION}

Orchids (Orchidaceae) are known as one of the largest and most diverse families of flowering plants, encompassing of more than 800 genera with 24, 000 species throughout the world (Zhang et al. 2015). Apart from its beautiful flowers, orchids are also known for their medicinal and commercial values (Tan et al. 2013). In 2016, a total of USD 3.2 million has been accounted in orchid exportation industry in Malaysia (Bernama 2017), making it one of the most sought-after flowering families in the floriculture industry. Examples of important orchid genera include Cattleya, Cymbidium, Dendrobium, and Phalaenopsis (Chin 2016).
Phalaenopsis bellina is a moth orchid species endemic to Borneo (Figure 1(A)). Naturally, it could be found growing on trees branches in shady lowland forests where it experiences wet and dry cycles and receives abundant sunlight. Besides, $P$. bellina is also known as the most iconic orchid species as it has strong unique biological features such as versatile colours flower, cereal fruit loops fragrance, elegant appearance and high commercial value (Chew et al. 2018). Furthermore, $P$. bellina is favoured amongst orchid farmer due to its lowcost of maintenance, ease of production and all year-round flowering habit. 
Previously, breeding programs had been employed in Phalaenopsis species to improve the flower colour, flowering time, petal shape, plant architecture and flower longevity for better commercial value (Lau et al. 2015). In addition, Phalaenopsis breeding also serves to conserve the species, which are on the verge of extinction. However, conventional breeding programme for Phalaenopsis plant is complicated due to its sexual incompatibility among the varieties, limited gene pool for desirable traits and it is extremely time consuming. Therefore, an alternative approach through genetic modification is seen to be more promising in improving the desirable traits of Phalaenopsis (Hsiao et al. 2011; Norman et al. 2017).

To date, only a handful of genetic modifications based on Agrobacterium-mediated transformation system have been demonstrated in Phalaenopsis (Gnasekaran et al. 2014; Hsing et al.2016; Li et al.2013). For instance, two diseaseresistant genes namely Gastrodia Antifungal Protein (GAFP) and Neutrophils Peptide-I (NPI) were successfully introduced in Doritaenopsis Tailin Angel Phalaenopsis by utilising Agrobacterium-mediated system (Li et al. 2013). Although Agrobacterium-mediated transformation is used in genetic modification of Phalaenopsis, this system still suffers several drawbacks like host range specific and not suitable for fast transient gene analysis. In contrast, particle bombardment transformation system provides a simple alternative for Phalaenopsis transformation. This method is rapid and offers no biological constraints or host limitations. It also allows foreign DNA of any sizes and conformations to be delivered into the host cells (Low et al. 2018; Que et al. 2014). Most importantly, the method also serves as a rapid system for transient gene analysis as well as producing stable transformants (Bhattacharyya et al. 2015; Ghorbanzade \& Ahmadabadi 2015; Wu et al. 2015). Despite being a powerful transformation system, its usage in Phalaenopsis genetic modification is limited, mainly due to the lack of an established protocol.

Therefore, this study was undertaken to develop an efficient $P$. bellina particle bombardment transformation protocol using green-fluorescent protein (GFP) and $\beta$-glucuronidase (GUS) as reporter systems. Ultimately, the optimized system could serve as a valuable platform for functional gene analysis and genetic modification of orchids.

\section{MATERIALS AND METHODS}

\section{PROTOCORM-LIKE-BODIES (PLBS) INDUCTION}

PLBs induction was performed according to Chew's methods (Chew et al. 2018). Briefly, three months old in vitro seedlings of $P$. bellina were used for protocorm-likebodies (PLBs) induction (Figure 1(B)). Young leaf segments of $P$. bellina were excised $(1.5 \mathrm{~cm} \times 1.5 \mathrm{~cm})$ and cultured on half strength (1/2) Murashige and Skoog (MS) medium supplemented with $0.8 \mu \mathrm{M}$ 2,4-dichlorophenoxyacetic acid (2,4-D), $100 \mathrm{mg} / \mathrm{L}$ myo-inositol, $0.5 \mathrm{mg} / \mathrm{L}$ niacin, $0.5 \mathrm{mg} / \mathrm{L}$ pyridoxine $\mathrm{HCl}, 2.0 \mathrm{mg} / \mathrm{L}$ glycine, $0.1 \mathrm{mg} / \mathrm{L}$ thiamine HCL, $20 \mathrm{~g} / \mathrm{L}$ sucrose and $3 \mathrm{~g} / \mathrm{L}$ gelrite to induce PLBs (Figure 1(C)). The $\mathrm{pH}$ of the medium culture was adjusted to $\mathrm{pH} 5.6$. The cultures were maintained under 16 $\mathrm{h} / 8 \mathrm{~h}$ (day/night) photoperiod with a photon flux of 150 $\mu \mathrm{mol} / \mathrm{m}^{2} \mathrm{~s}$ at $25 \pm 2^{\circ} \mathrm{C}$ for three months.

\section{PREPARATION OF TARGET TISSUE}

Individual PLB of approximately 2-3 mm diameter (Figure 1(E)) was separated aseptically from PLB clumps (Figure 1(D)) using scalpel. A total of 20 individual PLBs were arranged in the centre of a petri dish containing $1 / 2$ strength MS medium prior bombardment.

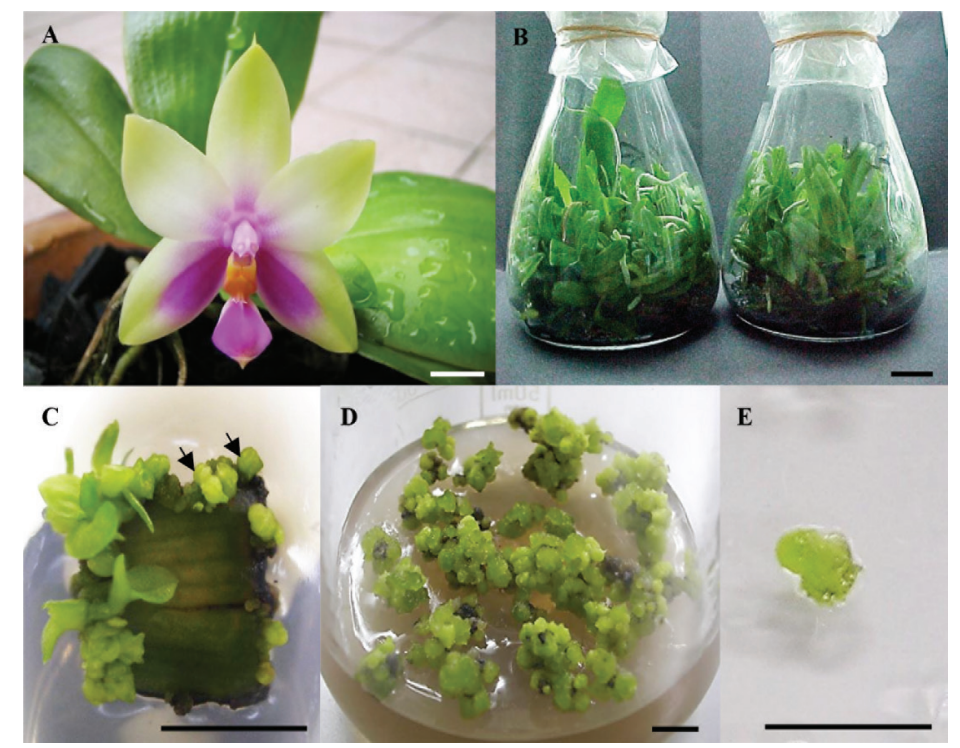

FIGURE 1. Establishment of P. bellina PLBs. (A) Potted P. bellina. (B) Three months old in-vitro P. bellina seedlings. (C) Induction of PLBs from leaf segment. Arrows indicating newly formed PLBs. (D) Clumps of PLBs cultured on $1 / 2$ MS medium $+0.8 \mu \mathrm{M}$ 2,4-D. (E) Individual PLB use for bombardment. Scale bars: $1 \mathrm{~cm}$ 


\section{PLASMID PREPARATION}

Two plasmids, namely p35sGFP and pSMCHS (supplementary Figure 1) were used in this study. The P35SGFP plasmid carries the sgfp gene while pSMCHS plasmid harbors the hptII and gusA genes. Both plasmids were driven by the CaMV35S promoter. Large scale plasmid DNA extraction was performed by using the Qiagen Plasmid Maxi kit (Qiagen, California) following the manufacturer's protocols.

\section{PARTICLE BOMBARDMENT TRANSFORMATION}

Particle bombardment transformation was performed using the PDS-1000/He Biolistic Particle Delivery System (Bio-Rad, California). Standard bombardment procedure was carried out following the manufacturer's manual instructions. The range of variations from the standard condition is listed in Table 1. Bombardment parameters were tested independently, while maintaining other conditions as in the standard procedure.

\section{SELECTION AND REGENERATION OF PUTATIVE PLBS TRANSFORMANTS}

Bombarded PLBS were cultured on hygromycin-free $1 / 2$ MS medium for a month to recover before they were transferred to $1 / 2 \mathrm{MS}$ medium supplemented with $4 \mathrm{mg} / \mathrm{L}$ of hygromycin for 5 weeks selection. Surviving putative transformants were proliferated on $1 / 2$ MS medium supplemented with $4 \mathrm{mg} / \mathrm{L}$ hygromycin and $10 \%(\mathrm{w} / \mathrm{v})$ banana homogenate (proliferation selection medium) for another 6 months. The hygromycin-resistant PLBs and plantlets (regenerated from PLBS) were maintained on $1 / 2$ MS medium supplemented with $4 \mathrm{mg} / \mathrm{L}$ of hygromycin to recover stable transgenic plants and avoid escapees. The transformation efficiency was calculated using the following formula;
Efficiency $=\frac{\text { Number of survived PLBs on the hygromycin selection plate } \times 100}{\text { Total number of PLBs bombarded }}$

\section{GFP TRANSIENT EXPRESSION MONITORING}

Bombarded PLBs were subjected to visual monitoring of their transient GFP expression as described by Lai et al. (2011). Briefly, the GFP expression of transformed PLBs clumps were observed under fluorescence microscope (Leica MZFL III) paired with GFP2 filter (Excitation filter: $480 / 40 \mathrm{~nm}$ ). The numbers of GFP expression spots on the PLBs were counted using the same magnification $(40 \times)$ to minimize discrimination. An imaging system (Leica DC 200) was attached to a fluorescence microscope to capture the image in real time using the Leica DC Viewer software.

\section{HISTOCHEMICAL GUS ASSAY}

The GUS assay was performed on transformed PLBs after 36 $\mathrm{h}$ post bombardment according to the protocol described by Lai (2016) with slight modifications. The transformants were immersed in X-gluc buffer ( $2 \mathrm{mM} \mathrm{X}$-gluc, $100 \mathrm{mM}$ sodium phosphate buffer ( $\mathrm{pH} 7.0), 0.5 \mathrm{mM}$ potassium ferricyanide and $0.5 \mathrm{mM}$ potassium ferrocyanide). Then, the transformants were incubated overnight at $37^{\circ} \mathrm{C}$ in darkness and washed with absolute ethanol. The number of blue spots observed was scored and viewed under $30 \mathrm{X}$ magnification power using Leica MZFL III microscope with normal light source without GFP filter.

\section{MOLECULAR CONFIRMATION OF TRANSFORMANTS}

The Nucleospin Plant II (Marchery Nagel, Germany) was used for genomic DNA extraction of putative $T_{3}$ clonal progenies PLBs transformants following the manufacturer's protocol. Using the genomic DNA as template, sgfp, gusA, and $h p t \mathrm{II}$ genes were amplified using gene specific primer

TABLE 1. Particle bombardment parameters analyzed independently for their effects on DNA delivery into the PLBs of $P$. bellina

\begin{tabular}{ll}
\hline Parameters & \multicolumn{1}{c}{ Bombardment conditions } \\
\hline Physical Parameters: & \\
Target tissues distance & $3,6,9,12 \mathrm{~cm}$ \\
Acceleration pressure & $650,900,1100,1350 \mathrm{psi}$ \\
Gold particles size & $0.6,1.0,1.6 \mu \mathrm{m}$ \\
Chamber vacuum pressure & $25,26,27,28 \mathrm{mmHg}$ \\
Number of bombardment & $1 \mathrm{X}, 2 \mathrm{X}, 3 \mathrm{X}$ \\
DNA coating on gold particles & $\mathrm{O}, \mathrm{S}, \mathrm{C}, \mathrm{SC}$ \\
Biological Parameters: & \\
Post bombardment incubation time & $12,24,36,48,60,72,84 \mathrm{~h}(\mathrm{~s})$ \\
Total plasmid amount & $0.5,1.0,1.5,2.0,2.5 \mu \mathrm{g}$ \\
Ratio (pSMCHS:p35SGFP) of the plasmid DNA & $0.00: 0.72,0.15: 0.12,0.11: 0.36$, \\
used in pmol (based on a total amount of $2 \mu \mathrm{g}$ & $0.07: 0.48,0.22: 0.00$ \\
loaded onto macrocarriers) & \\
\hline
\end{tabular}

O: Plasmid DNA was coated onto gold particle without the presence of calcium chloride and spermidine

S: Plasmid DNA was coated onto gold particle with the presence of spermidine only

C: Plasmid DNA was coated onto gold particle with the presence of calcium chloride only

SC: Plasmid DNA was coated onto gold particle with the presence of both calcium chloride and spermidine 
pairs (Table 2). The PCR conditions were as follows: initial denaturation step at $94^{\circ} \mathrm{C}$ for $5 \mathrm{~min}$, followed by 30 cycles of $94^{\circ} \mathrm{C}(30 \mathrm{~s}), 60^{\circ} \mathrm{C}(1 \mathrm{~min})$ and $72^{\circ} \mathrm{C}(2 \mathrm{~min})$ and a final extension step of $72^{\circ} \mathrm{C}$ for $7 \mathrm{~min}$.

\section{STATISTICAL ANALYSIS}

Each parameter in the optimisation experiment was carried out in triplicates with 20 individual PLBs per replicate. Data were analysed using one-way ANOVA in a completely randomised design and the differences contrasted using Tukey's multiple range test. All statistical analysis was performed at $5 \%(p=0.05)$ significance level using SPSS 20.0 (SPSS Inc. USA).

\section{RESULTS}

\section{TARGET DISTANCE AND ACCELERATION PRESSURE}

In this study, various parameters affecting the efficiency of $P$. bellina particle bombardment transformation system were evaluated. The transformation efficiency of $P$. bellina was evaluated based on the numbers of transient GFP and GUS spots counted on the bombarded PLBs following the previously reported protocol (Lai et al. 2011).

First, we evaluated the effects of distance between macrocarrier to target tissue. Based on our study, changes in target distance were found to significantly affect the transient GFP expression of bombarded PLBs (Figure 2(A)). The highest transient $g f p$ gene expression with 114 GFP spots/bombardment was observed at $6 \mathrm{~cm}$ target distance, followed by $9 \mathrm{~cm}$ (25 GFP spots/bombardment), $12 \mathrm{~cm}$ (19 GFP spots/bombardment), and $3 \mathrm{~cm}$ (15 GFP spots/ bombardment).

Varying acceleration pressures in P. bellina particle bombardment transformation also affected the total number of GFP spots on the PLBs (Figure 2(B)). In general, the GFP spots were found to increase proportionally with the acceleration but decreases at 1350 psi. The highest GFP spots (135 spots) were recorded at 1100 psi.

\section{SIZES OF GOLD PARTICLES AND VACUUM CHAMBER PRESSURE}

Optimisation of microparticle sizes is important as it could affect the efficiency of particle bombardment transformation. In this study, three different gold micro particles sizes $(0.6,1.0$ and $1.6 \mu \mathrm{m})$ were evaluated for the delivery of foreign genes into the PLBs. It was observed that the intermediate gold particle size $(1.0 \mu \mathrm{m})$ produced the highest transient GFP expressions as compared to 0.6 $\mu \mathrm{m}$ and $1.6 \mu \mathrm{m}$ (Figure 2(C)).

In Figure 2(D), it was noted that $27 \mathrm{mmHg}$ produce a significantly higher transient GFP expression (157 GFP spots/bombardment) in $P$. bellina PLBs. Lesser numbers of GFP transient expression (99 spots/bombardment) were observed at higher vacuum pressure $(28 \mathrm{mmHg})$.

\section{BOMBARDMENT NUMBER AND PRECIPITATION AGENTS}

As shown in Figure 2(E), different numbers of particle bombardment resulted in different numbers of GFP spot count. It was noted that single bombardment was recorded to be the most efficient way to introduce plasmid harbouring gfp gene into the PLBs. As the number of bombardment increased, the numbers of GFP spot decreased.

In addition, it was demonstrated that spermidine is a better binder as compared to calcium chloride and a combination of calcium chloride and spermidine. According to Figure 2(F), the combination of two precipitation agents resulted in three-fold lower GFP spot numbers per bombardment.

\section{POST BOMBARDMENT INCUBATION TIME, PLASMID DNA CONCENTRATION AND PLASMID DNA RATIO (CO- BOMBARDMENT SYSTEM)}

The transient GFP expression could be detected as early as $2 \mathrm{~h}$ post bombardment in P. bellina PLBs. The number of GFP spots increased as the post bombardment time increased. At $24 \mathrm{~h}$ post bombardment, the amount of GFP spots doubled (106 GFP spots/bombardment) as compared to $12 \mathrm{~h}$ post bombardment. Figure $3(\mathrm{~A})$ shows that the GFP spots/bombardment peaked at 36, 48, 60 and $72 \mathrm{~h}$ post bombardment with a range of 114 to 117 GFP spots/ bombardment. At $84 \mathrm{~h}$ post bombardment, the number of GFP count decreased by $21 \%$. Based on the results, the optimum time range for transient cells quantification through GFP spots counting were between 24 and $72 \mathrm{~h}$ post bombardment.

Efficiency of DNA transfer in particle bombardment is highly dependent on the plasmid DNA concentration used. According to the data presented in Figure 3(B), $2.0 \mu \mathrm{g}$ DNA per bombardment produced the highest transient GFP expression with 223 GFP spots/bombardment. Increasing

TABLE 2. List of primers used in genomic PCR for confirmation of PLB transformants

\begin{tabular}{lllc}
\hline Gene (Plasmid) & Primer & Primer sequence & Product length \\
\hline Gfp & Forward & 5'-ATG GTG AGC AAG GGC GAG GAG-3' & $750 \mathrm{bp}$ \\
(p35SGFP) & Reverse & 5'-TTA CTT GTA CAG CTC GTC CAT-3' & \\
gus A & Forward & 5'-CGC CGA TGC AGA TAT TCG TA-3' & $789 \mathrm{bp}$ \\
$(\mathrm{pSMCHS})$ & Reverse & 5'-ATT AAT GCG TGG TCG TGC AC-3' & \\
$h p t$ II & Forward & 5'-TCG TCC ATC ACA GTT TGC C-3' & $500 \mathrm{bp}$ \\
$(\mathrm{pSMCHS})$ & Reverse & 5'-AAA AGC CTG AAC TCA CCG C-3' \\
\hline
\end{tabular}



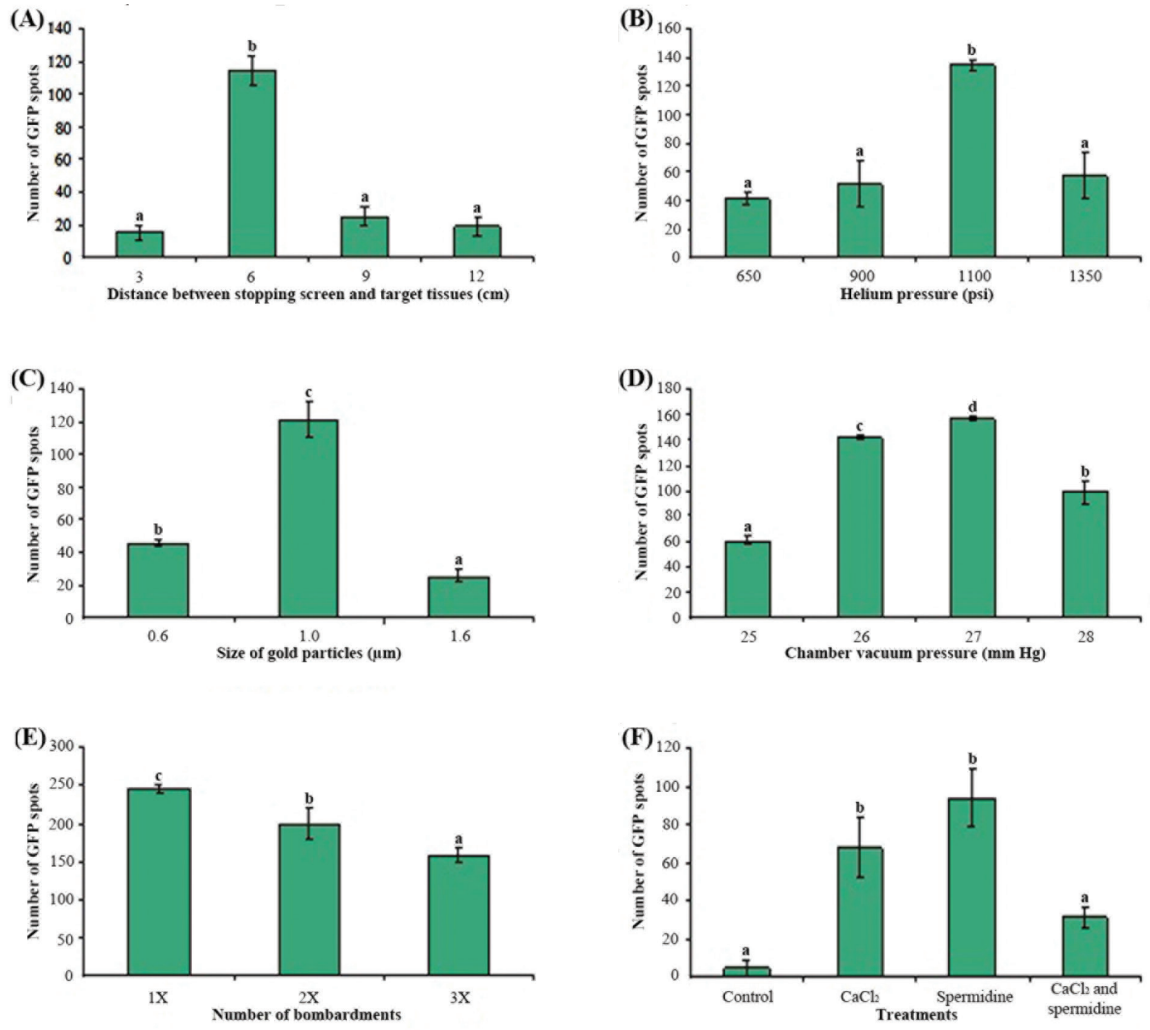

FIGURE 2. Effects of different physical parameters - (A) target distance, (B) helium pressure (psi), (C) gold particle size, (D) chamber vacuum pressure, (E) numbers of bombardment and (F) precipitation agents; the bombarded PLBs were evaluated using the GFP reporter system. Each parameter was investigated separately while others were maintained as the standard procedure (1100 psi, $6 \mathrm{~cm}$ target distance, $1.0 \mu \mathrm{m}$ gold particle size, $1 \mathrm{X}$ bombardment, $1 \mu \mathrm{g}$ plasmid DNA per bombardment in 1:1 ratio (for co-bombardment), $27 \mathrm{mmHg}$ chamber vacuum pressure and $2.5 \mathrm{M} \mathrm{CaCl}_{2}$ and $0.1 \mathrm{M}$ spermidine as the plasmid precipitation agents). Error bars correspond to standard deviations $(n=3)$. The average numbers of GFP spots were counted

per petri dish (20 individual PLBs in each dish). Different letters indicate values are significantly different at $p \leq 0.05$
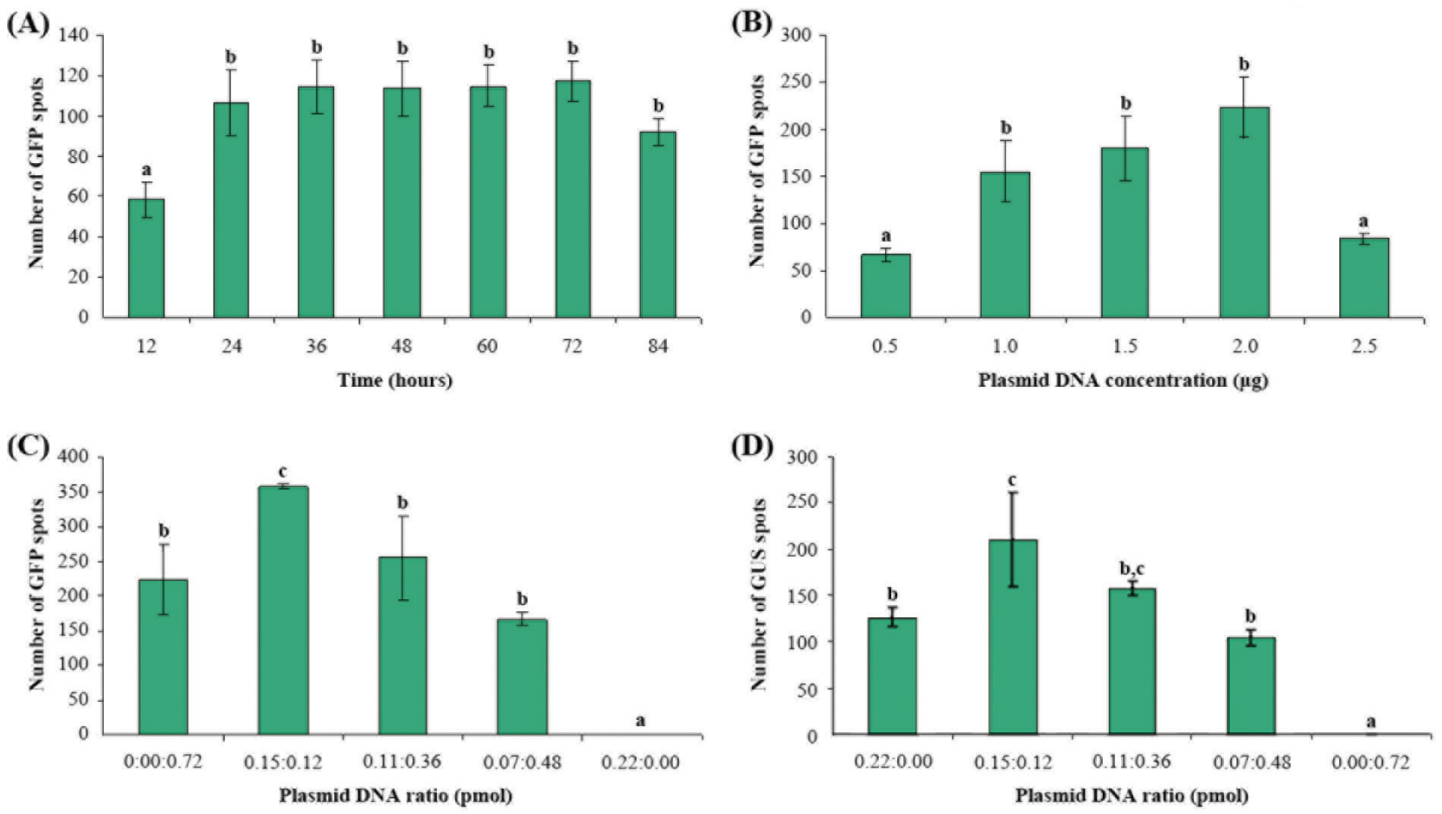

FIGURE 3. Effects of different biological parameters - (A) post bombardment time, and (B) plasmid DNA concentration on GFP transient expression for $P$. bellina PLBs. (C) and (D) showing the effects of different plasmid ratios (pSMCHS:p35SGFP) used for co-bombardment on GFP and GUS transient expressions in P. bellina PLBs. Data were collected $36 \mathrm{~h}$ post bombardment. Error bars correspond to standard deviations $(n=3)$. The average numbers of GFP/GUS spots were counted per petri dish

(20 individual PLBs in each dish). Different letters indicate values are significantly different $(p \leq 0.05)$ 
or reducing the DNA concentration beyond $2.0 \mu \mathrm{g}$ led to lower transient GFP expression.

Moreover, co-bombardment transformation was also attempted by utilising two different plasmids namely pSMCHS and p35SGFP. The ratios of the plasmids used were evaluated based on the numbers of GFP and GUS spots after $36 \mathrm{~h}$ post bombardment (Figures 4 and 5). Total co-bombardment DNA concentration was fixed at $2.0 \mu \mathrm{g}$ per bombardment with different ranges of plasmids ratio compositions. Apparently, for both the GFP and GUS systems, the 0.15:0.12 pmol ratio gained the highest GFP and GUS spots count, followed by 0.11:0.36 pmol, 0.22:0.00 pmol, and 0.07:0.48 pmol.

\section{SCREENING OF PUTATIVE TRANSFORMANTS}

The indirect selection strategy was deployed to allow the bombarded PLBs to stabilise for 30 days post bombardment on normal medium prior to antibiotic selection. Then, the co-bombarded individual PLBs under optimised condition were subjected to hygromycin selection of $P$. bellina transformants.

After growing two months on hygromycin selection medium, newly formed hygromycin-resistant cell clusters were observed from bombarded PLBs (Figure 6(B)). Out of 160 bombarded individual PLBs, three hygromycin resistant lines (line 1, line 2 and line 3 ) were successfully recovered; showing successful integration of the plasmid into the explants with the efficiency of $1.88 \%$.

To monitor the stability of the transgene(s), the previously mentioned hygromycin resistant lines were further subcultured on hygromycin selection medium for additional nine months, which all clonal progenies of hygromycin resistant lines were successfully recovered (100\% recovery rate). Interestingly, the recovered hygromycin resistant lines consistently showed strong and stable GFP expression (Figure 6(E) and 6(F)) as compared to the non-transformed tissues (control) (Figure 6(C)).

Subsequently, one $\mathrm{T}_{3}$ clonal progenies from each hygromycin resistant lines were subjected to PCR analysis to confirm the expression of $g f p$, gus A and $h p t \mathrm{II}$. PCR analysis was carried out on the using gene specific primer pairs listed in Table 2. All tested lines for PCR analysis showed the presence of $750 \mathrm{bp}, 789 \mathrm{bp}$ and $500 \mathrm{bp}$ products corresponding to $g f p, g u s \mathrm{~A}$ and hpt II genes (Figure 7(A), 7(B) and 7(C)). These results indicate a successful integration of co-bombarded $g f p$ and gus A genes into the genome of hygromycin resistant P. bellina. Each PCR analysis were accompanied with negative control. No $g f p$,

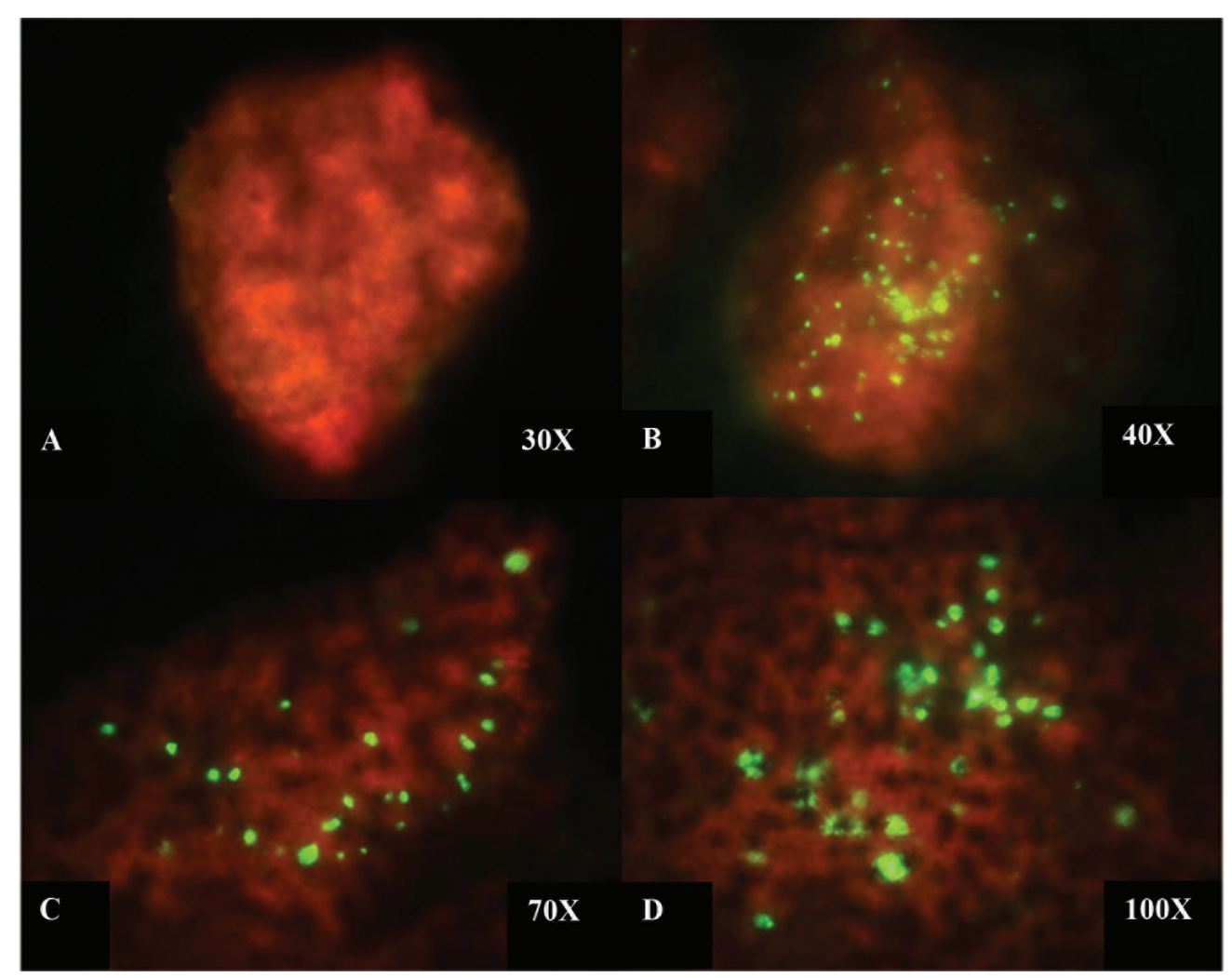

FIGURE 4. Transient GFP expression on PLBs of $P$. bellina $36 \mathrm{~h}$ after bombardment. PLBs were bombarded at optimum condition of $6 \mathrm{~cm}$ target tissue distance, 1100 psi acceleration pressure, $1.0 \mu \mathrm{m}$ gold particle size, 27 $\mathrm{mmHg}$ chamber vacuum pressure, single bombardment time, and use spermidine as DNA precipitation agent. (A) Negative control of non-bombarded PLBs (B - D) transient GFP expression on PLBs were visualised under blue light. All pictures were taken using Leica DC 200 imaging and Leica DC viewer software under a Leica MZFLIII fluorescence microscope equipped with GFP2 filters (Excitation filter: 480/40 nm).

The numeric on the right of each picture indicated the magnification power 


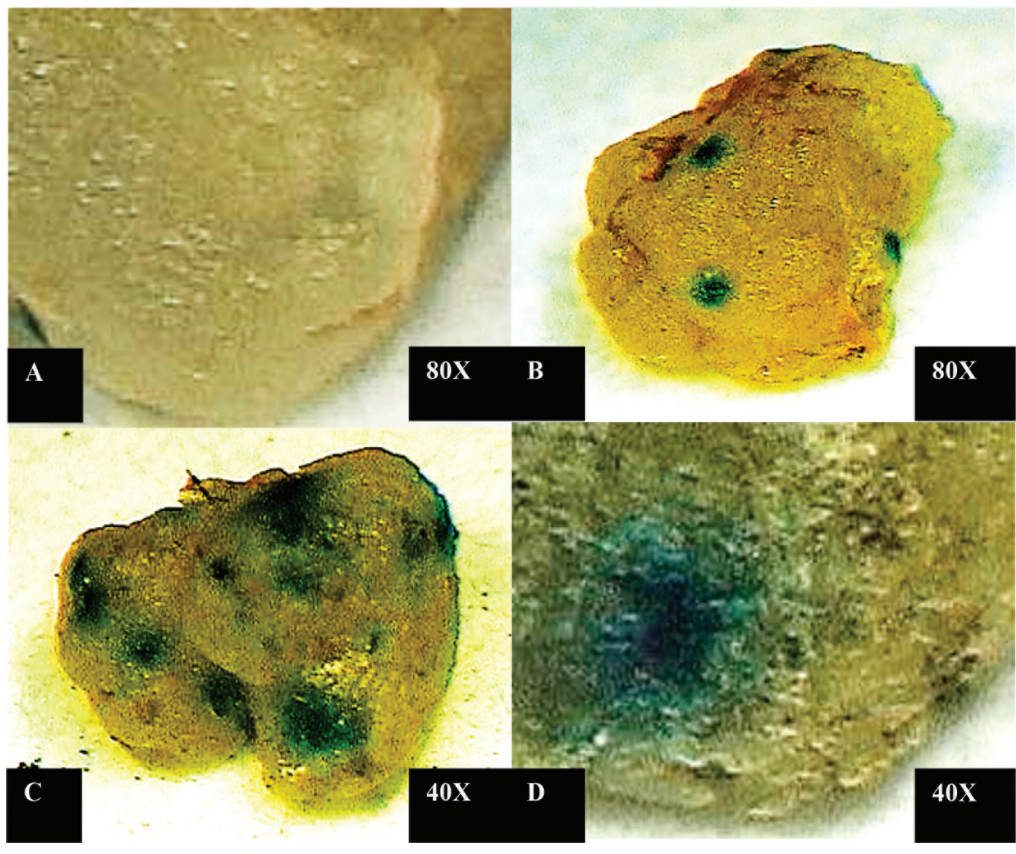

FIGURE 5. Transient GUS expression on PLBs of $P$. bellina. PLBs were bombarded at optimum condition of $6 \mathrm{~cm}$ target tissue distance, $1100 \mathrm{psi}$ acceleration pressure, $1.0 \mu \mathrm{m}$ gold particle size, $27 \mathrm{mmHg}$ chamber vacuum pressure, single bombardment time, and use spermidine as DNA precipitation agent. (A) Negative control of non-bombarded PLBs (B, C) GUS expressing cells were stained blue after GUS assay and the size of blue spots varied noticeably. (D) The margins of the GUS spots were diffused at high magnification. The numeric on the right of each picture indicated the magnification power

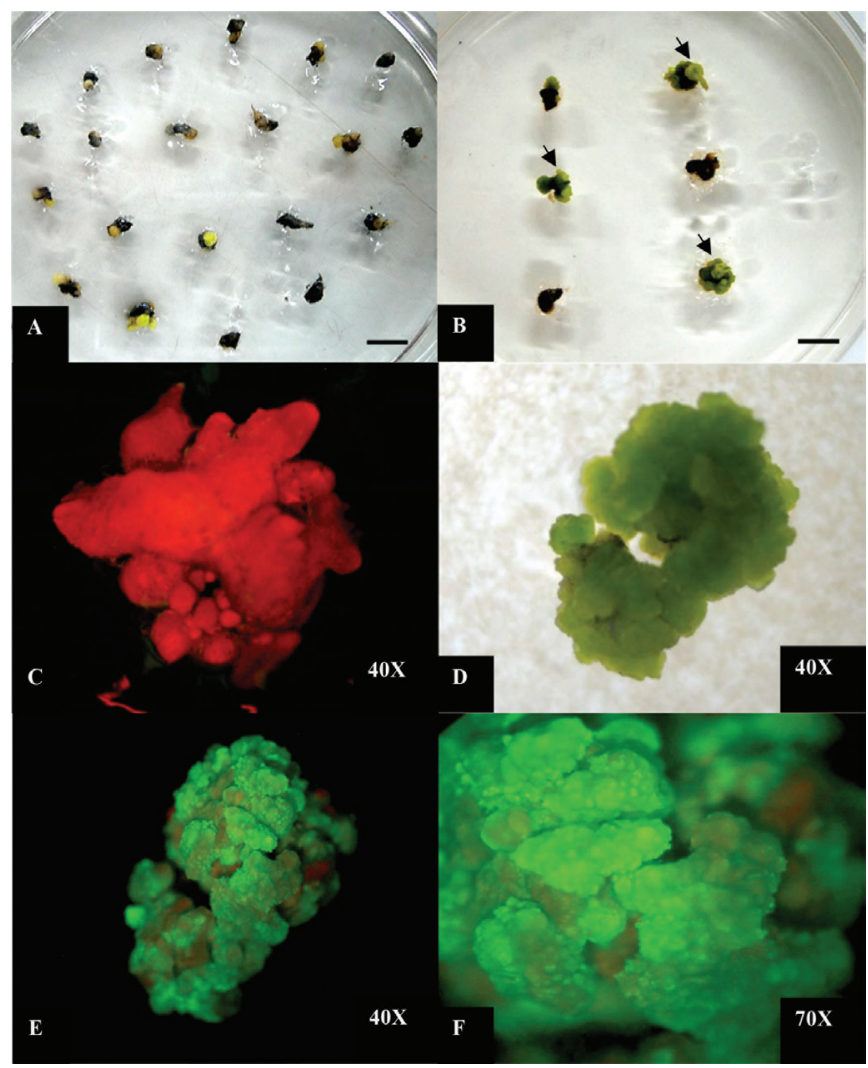

FIGURE 6. Stable GFP-expression pattern observed on PLBs clumps after 9 months cultured on hygromycin supplemented medium. (A) Post bombarded PLBs were cultured on hygromycin-free $1 / 2$ MS media. (B) Putative transformed PLBs cultured on proliferation selection medium. Arrows indicating newly formed hygromycin resistant cell clusters. (C) Non-transformed PLB clusters fluorescence in red. (D) Putative PLBs transformants viewed under white light. (E, F) GFP expressing PLBs were readily detected in young tissues (green fluorescence). Scale bars: $1 \mathrm{~cm}$ 

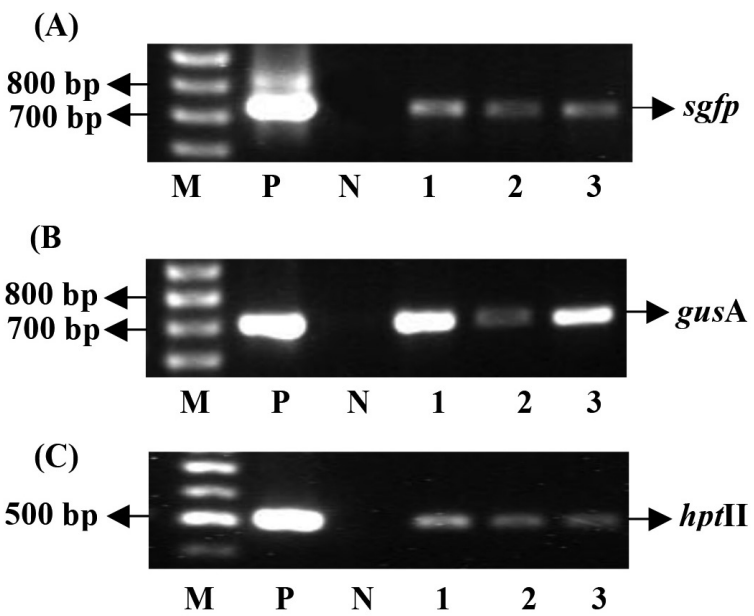

FIGURE 7. PCR analysis of gfp, gusA, and hptII genes in putative transformed of $P$. bellina $\mathrm{T}_{3}$ clonal progenies of hygromycin resistant lines PLBs. (A) PCR amplification of the specific $750 \mathrm{bp}$ gfp gene fragment from the putative transformed PLBs (B) PCR amplification of the gusA gene (800 bp) from the putative transformed PLBs (C) PCR amplification of the specific $500 \mathrm{bp}$ hptII gene fragment from the putative transformed PLBs. Lane M as the 100

bp DNA ladder, lane $\mathrm{P}$ as the positive control (PCR amplified gene from the respective plasmid), lane $\mathrm{N}$ as the negative control (non-transfomed PLBs) and lanes 1-3 as putative transformed $\mathrm{T}_{3}$ clonal progenies of hygromycin resistant lines PLBs 1-3

gus A and hptII genes band were observed in negative control for each $P C R$ analysis, indicating the presence of $g f p$, gus A and hptII product from PCR analysis was not affected by plasmid DNA contamination.

\section{DISCUSSION}

The particle bombardment-mediated system is an efficient and consistent physical process for gene transfer with no biological limitation (Que et al. 2014). However, the establishment of optimum parameters for plant transformations are required in any plant tissue used in particle bombardment to ensure successful gene delivery and high gene expression level in transgenic plants. In this study, we have successfully established and optimized parameters affecting particle bombardment transformation for PLBs of P. bellina. Both GUS and GFP were utilised to measure the efficiency of particle bombardment in PLBS of $P$. bellina. Reporter systems such as GFP, GUS and luciferase (LUC) are important elements in transient gene analysis as it is commonly used to evaluate the efficiency of transformation method (Jin et al. 2015; Lai \& Yusoff 2013; Lai et al. 2013; Lu et al. 2013).

One of the important parameters is the alteration of target distance which led to different expression of reporter gene in PLBs of P. bellina. Longer target distance could weaken the acceleration power even though the same acceleration pressure was used. However, shorter distance could increase acceleration power and damage the tissue. This parameter worked closely with acceleration pressure as mentioned by Atari and Folta (2019). Therefore, it is normal to observe less transient GFP expression when the low acceleration pressure was used as less penetration force was applied to the target tissue, which reduced transient
GFP expressions. In contrast, the high acceleration pressure is likely to cause severe injuries inflicted on the PLBs and less distribution of the particles and consequently affect the gene expression (Atari \& Folta 2019). Considering that PLBs of P. bellina is a clump of soft cells, combination of medium acceleration pressure (1100 psi) with medium target distance $(6 \mathrm{~cm})$ could be applied to avoid tissue damages while delivering exogenous gene into the PLBs.

Meanwhile, the intermediate gold particle sizes of $1.0 \mu \mathrm{m}$ was found to be the most efficient microcarrier size in delivering exogenous genes in PLBs. The usage of smaller microcarrier sizes was preferred as it reduced the mechanical injury on the target explants. However, study had shown that the influence of gold particle sizes were tissues and species specific (Mahdavi et al. 2014). Therefore, optimising this parameter is crucial for successful particle bombardment transformation.

In particle bombardment, vacuum pressure acts as a deceleration barrier and is responsible to preserve the velocity of the micro particle's travel through distant. In short, high vacuum pressure leads to stable velocity propellant to the target explant. It was recorded that the $P$. bellina PLBs could tolerate up to $27 \mathrm{mmHg}$ vacuum pressure. Wani et al. (2011) reported similar findings that $27 \mathrm{mmHg}$ was the optimum vacuum pressure to obtain optimum GUS transient expression in Dendrobium PLBs.

Our data also showed that single bombardment was the most efficient way to introduce plasmid harbouring gfp gene into the PLBs. As the number of bombardment increases, the explant is exposed to greater mechanical injury; hence, reducing the number of surviving cells expressing the reporter gene (Dhir et al.2010). Nonetheless, the parameter seemed to be species and tissues specific as GUS expression were significantly increased as the number 
(A)

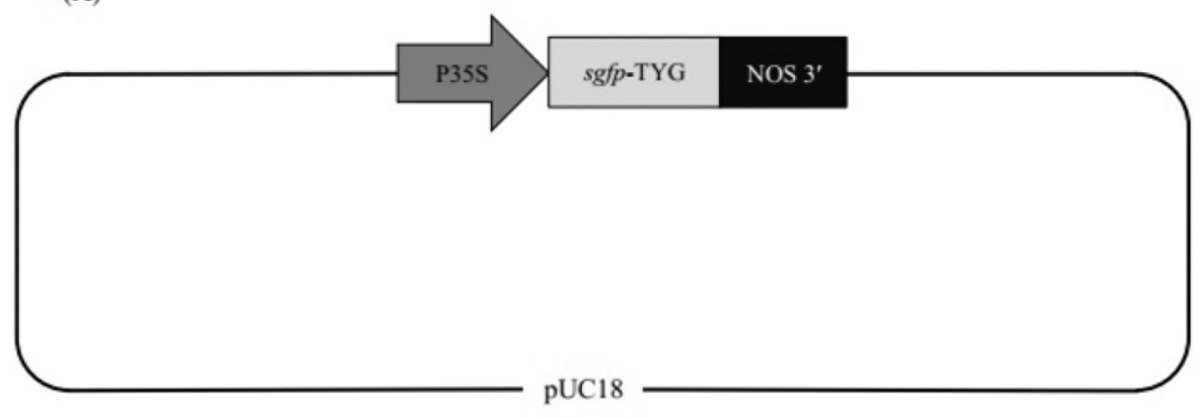

(B)

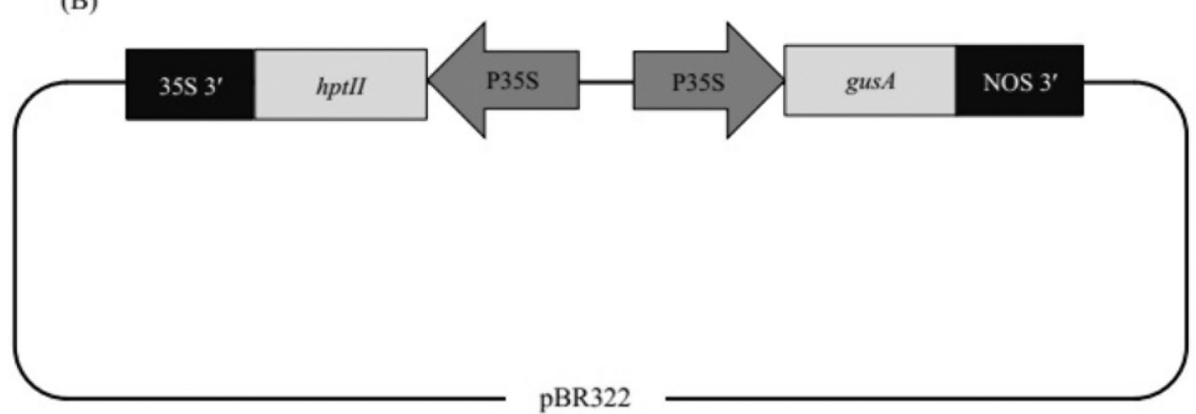

FIGURE S1. Schematic map of p35SGFP construct in pUC18 background and pSMCHS construct in pBR322 background. p35SGFP and pSMCHS harbour sgfp and gusA genes, respectively. Both plasmids were driven by the CaMV35S cauliflower mosaic virus 35S RNA promoter and nos 3' nopaline synthase terminator

of bombardment increased in rice (Hafiza et al. 2010) and orchid (Mahdavi et al. 2014) due to higher coverage of the target area and increased efficiency.

Calcium chloride and spermidine are common precipitation agents, which help the DNA of interest to bind to the gold particle. In this study, it was demonstrated that spermidine is a better binder as compared to calcium chloride and a combination of calcium chloride and spermidine. However, the cause of these phenomena remains unknown and it is hypothesized that the biochemical reaction between both precipitation agents was not favourable for $P$. bellina PLBs to produce the transient expression.

Next, the required concentration of plasmid DNA could be prepared with the spermidine. However, amount of plasmid DNA used in particle bombardment system need to be optimised in order to obtain maximum transformation efficiency. Several reports indicated that gene transfer efficiency could be enhanced by increasing the DNA concentration to the optimum level as what had been observed in banana (Mahdavi et al. 2014), orchid (Gnasekaran et al. 2014), and soybean (Li et al. 2017). As indicated in Figure 3(B), increasing or reducing the DNA concentration beyond $2.0 \mu \mathrm{g}$ led to lower transient GFP expressions. High DNA concentration encouraged the formation of large DNA aggregation, leading to higher cell mechanical injury, whereas low DNA concentration was insufficient to coat the total amount of microcarriers used.

Following the optimised parameters, co-bombardment with two types of plasmid was also attempted in this study. In co-bombardment studies, optimisation of the plasmid ratio used is crucial for successful transformation. Apparently, for both the GFP and GUS systems, the 0.15:0.12 pmol ratio (pSMCHS:p35SGFP) gained the highest transient expression. However, it is hypothesized that the ratio of plasmid used in co-bombardment transformation is species and type of target explant dependent (Lao et al. 2014; Maraschin et al. 2009). Thus, proper adjustment of the plasmid ratio is required prior transformation.

Following the co-bombardment, the PLBs were subjected to antibiotic selection for generation of stable transformants of $P$. bellina. In this study, indirect selection strategy was used as this selection method allowed active proliferation of putative transformed tissues or cells to produce sufficient resistant cell lines to tolerate the toxicity of hygromycin. According to Zhao et al. (2017), the timing of selection post bombardment may also influence the transformation efficiency. This was also supported by da Silva and Tanaka (2011) which stated that putative transformants should be grown on selection agent free medium in order to allow the explants to recover from the damages caused during the particle bombardment process.

The survived antibiotic resistant PLBs were continuously grown on hygromycin selection media for subsequent nine months. Clonal progenies of putative $P$. bellina of $\mathrm{T}_{3}$ transformants were then subjected to genomic PCR analysis to confirm the stable integration of transgene into the genome by using gene specific primer pairs (Table 2). Genomic PCR analysis had been widely adapted in particle bombardment transformation in order 
to assess integration of the gene in the explant's genome (Lai et al. 2012). Based on the genomic PCR analysis, stable integration of co-bombarded $g f p$ and gus A genes into the genome of $P$. bellina were successfully performed in this optimised protocol.

\section{CONCLUSION}

Taken together, both physical and biological parameters affecting particle bombardment mediated transformation system of $P$. bellina were successfully optimized. To the best of our knowledge, this is the first study on particle bombardment transformation of $P$. belina. Ultimately, results gathered from this study serve as a valuable platform for functional gene analysis and genetic modification of orchids for trait improvement.

\section{ACKNOWLEDGEMENTS}

This research is supported by UPM Putra Grant (GPIPM/2015/9450800). We thank the members of Floral Biotechnology Laboratory (FBL), Universiti Putra Malaysia (UPM) for their technical assistance and support.

\section{REFERENCES}

Atari, M.F.B.M. \& Folta, K.M. 2019. Transformation improvement with the Standardized Pressure Agrobacterium Infiltration Device (SPAID). BMC Research Notes 12(1): 144.

Bernama. 2017. Ahmad Shabeery: Orchid Export Increases to RM13.2m Last Year. http://www.thesundaily.my/ news/2205891. Accessed on 9 June 2017.

Bhattacharyya, J., Chakraborty, A., Roy, S., Pradhan, S., Mitra, J., Chakraborty, M., Manna, A., Sikdar, N., Chakraborty, S. \& Sen, S.K. 2015. Genetic transformation of cultivated jute (Corchorus capsularis L.) by particle bombardment using apical meristem tissue and development of stable transgenic plant. Plant Cell, Tissue and Organ Culture 121(2): 311-324.

Chew, Y.C., Abd-Halim, M.H., Wan-Abdullah, W.M.A.N., OngAbdullah, J. \& Lai, K.S. 2018. Highly efficient proliferation and regeneration of protocorm-like bodies (PLBs) of the threatened endemic orchid: Phalaenopsis bellina. Sains Malaysiana 47(6): 1093-1099.

Chin, C.F. 2016. The proteome of orchids. In Agricultural Proteomics Volume 1: Crops, Horticulture, Farm Animals, Food, Insect and Microorganisms, edited by Salekdeh, G.H. Switzerland: Springer International Publishing. pp. 127-135.

da Silva, T.J.A. \& Tanaka, M. 2011. Optimization of particle bombardment conditions for hybrid Cymbidium: Part II. Transgenic Plant Journal 5(1): 78-82.

Dhir, S., Knowles, K. \& Pagan, C.L. 2010. Optimization and transformation of Arundo donax L. using particle bombardment. African Journal of Biotechnology 9(39): 6460-6469.

Ghorbanzade, Z. \& Ahmadabadi, M. 2015. Stable transformation of the Saintpaulia ionantha by particle bombardment. Iran Journal of Biotechnology 13(1): 11-16.

Gnasekaran, P., Antony, J.J.J., Uddain, J. \& Sreeramanan, S. 2014. Agrobacterium-mediated transformation of the recalcitrant Vanda Kasem's Delight orchid with higher efficiency. Scientific World Journal 2014(1): 583934.
Hafiza, M.R., Roowi, S., Subramaniam, S., Kamaruzaman, R. \& Zuraida, A.R. 2010. Factors affecting delivery and transient expression of gusA gene in Malaysian indica rice MR 219 callus via biolistic gun system. Journal of Biotechnology 9(51): 8810-8818.

Hsiao, Y.Y., Pan, Z.J., Hsu, C.C., Yang, Y.P., Hsu, Y.C., Chuang, Y.C., Shih, H.H., Chen, W.H., Tsai, W.C. \& Chen, H.H. 2011. Research on orchid biology and biotechnology. Plant and Cell Physiology 52(9): 1467-1486.

Hsing, H.X., Lin, Y.J., Tong, C.G., Li, M.J., Chen, Y.J. \& Ko, S.S. 2016. Efficient and heritable transformation of Phalaenopsis orchids. Botanical Studies 57(1): 30. doi: https://doi. org/10.1186/s40529-016-0146-6.

Jin, T., Wang, J., Zhu, X., Xu, Y., Zhou, X. \& Yang, L. 2015. A new transient expression system for large-scale production of recombinant proteins in plants based on air-brushing an Agrobacterium suspension. Biotechnology Reports 6(1): 36-40.

Lai, K.S. 2016. Analysis of EXO70C2 expression revealed its specific association with late stages of pollen development. Plant Cell, Tissue and Organ Culture 124(1): 209-215.

Lai, K.S. \& Yusoff, K. 2013. Production of tENDO1 in stably transformed tobacco cell cultures for mismatch detection. Plant Cell, Tissue and Organ Culture 114(2): 287-294.

Lai, K.S., Yusoff, K. \& Mahmood, M. 2013. Functional ectodomain of the hemagglutinin-neuraminidase protein is expressed in transgenic tobacco cells as a candidate vaccine against Newcastle disease virus. Plant Cell, Tissue and Organ Culture 112(1): 117-121.

Lai, K.S., Yusoff, K. \& Mahmood, M. 2012. Heterologous expression of hemagglutinin-neuraminidase protein from newcastle disease virus strain AF2240 in Centella asiatica. Acta Biologica Cracoviensia. Series Botanica 54(1): 142-147.

Lai, K.S., Abdullah, P., Yusoff, K. \& Mahmood, M. 2011. An efficient protocol for particle bombardment-mediated transformation of Centella asiatica callus. Acta Physiologiae Plantarum 33(6): 2547-2552.

Lao, J., Ai, O., Bromley, J.R., McInerney, P., Suttangkakul, A., Smith-Moritz, A.M., Plahar, H., Chiu, T.Y., Fernández-Niño, S.M.G., Ebert, B., Yang, F., Christiansen, K.M., Hansen, S.F., Stonebloom, S., Adams, P.D., Ronald, P.C., Hillson, N.J., Hadi, M.Z., Vega-Sánchez, M.E., Loqué, D., Scheller, H.V. \& Heazlewood, J.L. 2014. The plant glycosyltransferase clone collection for functional genomics. The Plant Journal 79(3): 517-529.

Lau, S.E., Schwarzacher, T., Othman, R.Y. \& Harikrishna, J.A. 2015. dsRNA silencing of an R2R3-MYB transcription factor affects flower cell shape in a Dendrobium hybrid. BMC Plant Biology 15(1): 194. doi: 10.1186/s12870-015-0577-3.

Li, J., Kuang, P., Liu, R.D., Wang, D., Wang, Z.N. \& Huang, M.R. 2013. Transfer of the gafp and npi, two disease-resistant genes, into a phalaenopsis by Agrobacterium tumefaciens. Pakistan Journal of Botany 45(5): 1761-1766.

Li, S., Cong, Y., Liu, Y., Wang, T., Shuai, Q., Chen, N., Gai, J. \& Li, Y. 2017. Optimization of Agrobacterium-mediated transformation in soybean. Frontiers in Plant Science 8(1): 246.

Low, L.Y., Yang, S.K., Andrew Kok, D.X., Ong-Abdullah, J., Tan, N.P. \& Lai, K.S. 2018. Transgenic plants: Gene constructs, vector and transformation method. In New Visions in Plant Science, edited by Çelik, Ö. Croatia: Intech Open. pp. 41-61.

Lu, Y., Chen, X., Wu, Y., Wang, Y., He, Y. \& Wu, Y. 2013. Directly transforming PCR-amplified DNA fragments into plant cells 
is a versatile system that facilitates the transient expression assay. PLoS ONE 8(2): e57171.

Mahdavi, F., Mahmood, M. \& Noor, N. 2014. Optimization of particle bombardment parameters for DNA delivery into the male flowers of banana. Biologia (Bratislava) 69(7): 888-894.

Maraschin, F.D.S., Memelink, J. \& Offringa, R. 2009. Auxin-

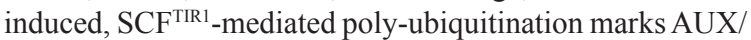
IAA proteins for degradation. The Plant Journal 59(1): 100-109.

Noman, A., Aqeel, M., Deng, J., Khalid, N., Sanaullah, T. \& Shuilin, H. 2017. Biotechnological advancements for improving floral attributes in ornamental plants. Frontier in Plant Science 8(1): 530.

Que, Q., Elumalai, S., Li, X., Zhong, H., Nalapalli, S., Schweiner, M., Fei, X., Nuccio, M., Kelliher, T., Gu, W., Chen, Z. \& Chilton, M.D. 2014. Maize transformation technology development for commercial event generation. Frontier in Plant Science 5(1): 379.

Tan, B.C., Chin, C.F., Liddell, S. \& Alderson, P. 2013. Proteomic analysis of callus development in Vanilla planifolia Andrews. Plant Mololecular Biology Reporter 31(6): 1220-1229.

Wani, S.H., Sanghera, G.S., Haribhushan, A., Singh, N.B. \& Gosal, S.S. 2011. Bio-physical parameters affecting transient GUS expression in Indica rice variety PAU 201 via particle bombardment. Elixir Bio Technology 34(2011): 2496-2501.

Wu, H., Awan, F.S., Vilarinho, A., Zeng, Q., Kannan, B., Phipps, T. \& McCuiston, J. 2015. Transgene integration complexity and expression stability following biolistic or Agrobacteriummediated transformation of sugarcane. In Vitro Cellular \& Developmental Biology-Plant 51(6): 603-611.

Zhang, S.B., Chen, W.Y., Huang, J.L., Bi, Y.F. \& Yang, X.F. 2015. Orchid species richness along elevational and environmental gradients in Yunnan, China. PLoS ONE 10(11): e0142621.
Zhao, Y., Zhang, Y., Su, P., Yang, J., Huang, L. \& Gao, W. 2017. Genetic transformation system for woody plant Tripterygium wilfordii and its application to product natural celastrol. Frontiers in Plant Science 8(1): 2221.

Wan Muhamad Asrul Nizam Wan Abdullah, De-Xian Andrew Kok \& Janna Ong-Abdullah

Department of Cell and Molecular Biology

Faculty of Biotechnology and Biomolecular Sciences

Universiti Putra Malaysia

43400, Serdang, Selangor Darul Ehsan

Malaysia

Yee-Chern Chew \& Maziah Mahmood

Department of Biochemistry

Faculty of Biotechnology and Biomolecular Sciences Universiti Putra Malaysia

43400, Serdang, Selangor Darul Ehsan

Malaysia

Kok-Song Lai*

Health Sciences Division

Abu Dhabi Women's College

Higher Colleges of Technology

41012 Abu Dhabi

United Arab Emirates

*Corresponding author; email: lkoksong@hct.ac.ae

Received: 26 September 2018

Accepted: 25 June 2019 